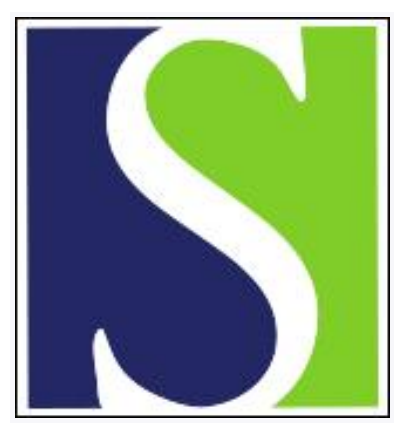

Scand J Work Environ Health 1982;8(3):201-208

https://doi.org/10.5271/sjweh.2475

Issue date: Sep 1982

Antimony in lung, liver and kidney tissue from deceased smelter workers.

by Gerhardsson L, Brune D, Nordberg GF, Wester PO

This article in PubMed: www.ncbi.nlm.nih.gov/pubmed/7156939

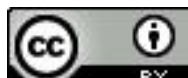




\title{
Antimony in lung, liver and kidney tissue from deceased smelter workers
}

\author{
by Lars Gerhardsson, MD, ${ }^{1,2}$ Dag Brune, PhD, ${ }^{3}$ Gunnar F Nordberg, MD, ${ }^{2}$ \\ Per O Wester, MD'
}

\begin{abstract}
GERHARDSSON L, BRUNE D, NORDBERG GF, WESTER PO. Antimony in lung, liver and kidney tissue from deceased smelter workers. Scand $j$ work environ health 8 (1982) 201-208. Tissue concentrations of antimony in lung, liver, and kidney tissue from a group of deceased smelter workers from northern Sweden have been compared with those of a group of persons without occupational exposure from a nearby area. Neutron activation analysis was used to determine the antimony concentration of lung tissue from exposed workers; these concentrations were 12-fold higher than those of referents $(p<0.001)$. For lung tissue there was no tendency towards decreased antimony concentrations with time (up to 20 a) after the cessation of exposure, and this result indicates a long biological half-time. The highest values were found for workers who had worked for many years at the roasters and in the arsenic and selenium departments. There was no significant difference between the antimony concentration of the lung tissue from workers who had died of lung cancer and those of persons who died of other malignancies, cardiovascular disease, or other causes. This finding does not however rule out the possibility of a role for antimony in the etiology of lung cancer among smelter workers since multiple factors may have been operating. The antimony concentration of the liver tissue and the kidney cortex did not differ from the corresponding values of the reference group; this finding indicates either a short biological half-time or insignificance for the systemic distribution of antimony.
\end{abstract}

Key terms: neutron activation analysis.

For many metals, the tissue concentration in exposed industrial workers has only been investigated to a limited extent. The concentrations of various trace elements in lung, liver, and kidney tissue have therefore been investigated for deceased smelter workers who were exposed to a large number of metals and other elements at Rönnskärsverken near Skellefteå $(1,2,27)$. Corresponding investigations have also been carried out with a reference group from the districts of Burträsk and Jörn, situated some $50 \mathrm{~km}$ from Skellefteå. Increased knowledge of various metal concentrations in tissue is of great value as

1 Department of Medicine, Umeå University, Umeå, Sweden.

2 Department of Environmental Medicine, Umeå University, Umeå, Sweden.

3 Scandinavian Institute of Dental Materials, Oslo, Norway.

Reprint requests to: Dr L Gerhardsson, Department of Environmental Medicine, Umeå University, S-901 87 Umeå, Sweden. background data in studies of the toxicity of trace elements and as a basis for the establishment of hygienic standards for the occupational environment.

In an earlier report (35) arsenic and selenium concentrations in lung, liver, and kidney tissue from deceased smelter workers at Rönnskärsverken were presented. In nature antimony occurs together with other metals such as copper and arsenic in certain sulfide ores. It is known that smelter workers can be occupationally exposed to antimony. Investigations have shown that such workers at Rönnskärsverken, especially at the roasters and in the arsenic departments, have an increased risk for lung cancer (32). An increased level of arsenic has also been found in lung tissue from these smelter workers (35). Antimony exposure occurs in the same work environments, which, however, have been incompletely surveyed, both with regard to the type of chemical compounds which occurs and to the possible effects on 
health. To throw some light on the importance of antimony, this paper reports and discusses the concentrations found and presents an interpretation of the results in relation to different causes of death.

\section{Antimony}

The metal antimony is an element with atomic number 51 in the periodic system. It belongs to the same periodic group as arsenic, and there are both chemical and biological similarities between these metals (8). Antimony and its compounds have a variety of uses (18). The metal antimony is used, for instance, with other metals such as tin, lead, and copper to increase the hardness of alloys. Antimony trioxide and antimony pentoxide are used for producing fireproofing chemicals and textiles. Organic antimony salts are used in pharmacological preparations for schistosomiasis and leischmaniasis. Occupational exposure to antimony and its compounds can occur in connection with all the uses presented and also in the handling of antimony-containing material in certain smelters.

\section{Biological half-time in the lung}

The elimination of chemical substances from the lung is dependent upon their solubility in the lung tissue fluid. As regards antimony compounds specifically, our knowledge is limited. A study on beagles exposed to labeled antimony aerosols indicated an initial fast clearance. After a few days up to $80 \%$ of the amount given had been eliminated (whole-body measurement). The rapid elimination phase was followed by a slow phase with a half-time in whole body of $36-100 \mathrm{~d}$ (10). The retention of the initial lung burden in the lung was $0.03-5.7 \%$ after four months, dependent upon the type of particles. Excretion of antimony occurred via urine and feces with a ratio of 0.8 .

The biological half-time in man has not yet been investigated completely. For a pensioned antimony worker with so-called antimony pneumoconiosis, one author (20) found a decrease of approximately half the initial value of urinary antimony concentration 4 a after cessation of exposure. Pathological lung findings, as observed in radiographs, did not diminish during this time.

\section{Lung changes and industrial exposure}

Antimony trioxide can give rise to a picture resembling pneumoconiosis on lung radiographs $(4,15,16,20,21,22,23,24)$.

The changes are similar to those of siderosis or the simple pneumoconiosis of coal workers (21). Also laryngitis (29), tracheitis $(9,29)$, and pneumonitis $(29)$ have been found in men subjected to antimony exposure, presumably in the form of antimony trioxide. These observations have not been verified by other authors - but pneumonitis has been found in animal experiments (12) with high exposure, and the exposure was higher in the study in which pneumonitis was found (29) than in other studies. It has been reported that acute exposure to antimony pentachloride can give rise to lung edema $(5,6)$.

\section{Subjects and methods}

The subjects consisted of 40 deceased men who had worked at Rönnskärsverken, a smelter and refinery in northern Sweden, and who died during the period 19761978. As referents, 11 age-matched men were selected from a rural area (Burträsk \& Jörn), approximately $50 \mathrm{~km}$ from the factory. Neither in the index group nor in the reference group was any selection made as regards diagnosis. The average age of the workers was 66.6 a and that of the reference group $67.5 \mathrm{a}$. In all, 15 of the workers died from malignancies, six from respiratory cancer. A total of 17 of the workers died from cardiovascular diseases, and eight from other causes. In the reference group seven died from myocardial infarction and three from cerebrovascular diseases.

No difference was found in the time of exposure between workers dead from malignancies in comparison to workers dead from other causes (average 30.9 and 31.3 a, respectively).

Smoking habits and history of employment were obtained from questionnaires answered by relatives. Information about occupations at the factory was given by the company. 


\section{Preparation of the material}

The instruments used for specimen collection were made of quartz glass to avoid contamination. Specimens of about $2 \mathrm{~g}$ of wet weight were taken about $1 \mathrm{~cm}$ below the diaphragmatic surface of the right liver lobe, and the same amount of kidney cortex was taken from the right upper part. The samples were transferred to cleaned quartz ampuls and freeze-dried. Specimens of about $10 \mathrm{~g}$ of wet lung tissue were dissected from the lower part of the right upper lobe. The lung samples were deep-frozen and ground to powder with a quartz pestle in a quartz mortar, and about $2 \mathrm{~g}$ of the powder was transferred to quartz ampuls and freeze-dried. The ampuls were sealed by flame and were then ready for irradiation.

Most of the specimens were irradiated with a thermal neutron flux of $2 \times 10^{3}$ $\mathrm{n} /\left(\mathrm{cm}^{2} \cdot \mathrm{s}\right)$ for $3 \mathrm{~d}$ in the $\mathrm{R} 2$ reactor at Studsvik. Chemical separation was performed with an automated ion-exchange technique, and gamma spectrometric measurements were carried out on the separated fractions as described earlier (30).

\section{Statistical methods}

Earlier investigations have shown that trace elements in tissues do not usually follow a normal distribution $(14,28,34)$. Wilcoxon's rank sum test was therefore used in the statistical work, and the median values for the antimony concentrations in lung, liver, and kidney tissue have been given for both the workers and the referents. The Student's t-test was used for the calculations of the possible differences with regard to mean age, duration of exposure, and length of retirement.

\section{Results}

Antimony concentrations in lung tissue were available from all of the 40 deceased smelter and refinery workers and from the 11 referents. For 21 of the workers and 8 of the referents antimony concentrations were also determined in the liver and kidney cortex.

The 40 workers were divided into three groups based upon the main autopsy diagnosis as follows:
Group I: 15 workers dead from malignancies

Group II: 17 workers dead from cardiovascular diseases

Group III: 8 workers dead from other causes

Age, diagnosis, smoking habits, time of exposure, length of retirement, and the antimony concentrations of the lung, liver, and kidney tissue of the deceased smelter workers and the referents are presented in tables 1-4. Table 1 presents values for workers in group I, table 2 values for workers in group II, table 3 values for workers in group III, and table 4 values for the referents. Fig 1 presents the concentration of antimony in lung tissue from smelter workers in relation to length of retirement [correlation coefficient $\left(\mathrm{r}^{2}\right)=$ $0.002]$.

The median value of antimony in lung tissue from all the smelter workers was $315 \mu \mathrm{g} / \mathrm{kg}^{4}(2.6 \mu \mathrm{mol} / \mathrm{kg})$, a level 12-times higher than the median value of the referents $(p<0.001)$. Workers in group I had a median value of $330 \mu \mathrm{g} / \mathrm{kg}(2.7 \mu \mathrm{mol} / \mathrm{kg})$, workers in group II $220 \mu \mathrm{g} / \mathrm{kg} \quad(1.8$ $\mu \mathrm{mol} / \mathrm{kg}$ ), and workers in group III 360 $\mu \mathrm{g} / \mathrm{kg}(3.0 \mu \mathrm{mol} / \mathrm{kg})$. The values of all three groups were significantly higher $(p<0.001)$ than that of the reference group $[26 \mu \mathrm{g} / \mathrm{kg}(0.2 \mu \mathrm{mol} / \mathrm{kg})]$, but they did not differ significantly from each other. The median value for antimony in the liver tissue and kidney cortex of the workers, $12 \mu \mathrm{g} / \mathrm{kg}(0.10 \mu \mathrm{mol} / \mathrm{kg})$ and $6 \mu \mathrm{g} / \mathrm{kg}(0.05 \mu \mathrm{mol} / \mathrm{kg})$, respectively, did not differ significantly from the median values of the reference group, $7 \mu \mathrm{g} / \mathrm{kg}$ $(0.06 \mu \mathrm{mol} / \mathrm{kg})$ and $5 \mu \mathrm{g} / \mathrm{kg}(0.04 \mu \mathrm{mol} / \mathrm{kg})$, respectively. Furthermore, no significant differences were found between the three groups of deceased workers with respect to the median value for antimony in liver tissue and kidney cortex.

The highest level of antimony in lung tissue $[5,480 \mu \mathrm{g} / \mathrm{kg}(45.0 \mu \mathrm{mol} / \mathrm{kg})]$ was found for a worker who had worked for 13 a at the roasters, which, according to statistics on acute etching and gas accidents, and also with regard to exposure to dust, arsenic, sulfur dioxide, etc, has had

4 Note: $\mu \mathrm{g} / \mathrm{kg}$ of wet weight. 
Table 1. Tissue concentrations ( $\mu \mathrm{g} / \mathrm{kg}$ wet weight) a of antimony (Sb) in exposed workers with malignancies.

\begin{tabular}{|c|c|c|c|c|c|c|c|}
\hline $\begin{array}{l}\text { Age } \\
\text { (a) }\end{array}$ & Diagnosis $\mathbf{b}$ & Smoking habits & $\begin{array}{l}\text { Length of } \\
\text { retirement } \\
\text { (a) }\end{array}$ & $\begin{array}{l}\text { Time of } \\
\text { exposure } \\
\text { (a) }\end{array}$ & $\begin{array}{l}\text { Lung } \\
\mathrm{Sb}\end{array}$ & $\begin{array}{l}\text { Liver } \\
\text { Sb }\end{array}$ & $\begin{array}{l}\text { Kidney } \\
\mathrm{Sb}\end{array}$ \\
\hline 71 & Lung cancer (1) & Unknown & 5 & 41 & 2,550 & 97 & 47 \\
\hline 71 & Lung cancer (2) & Cigarette smoker & 6.5 & 37 & 450 & 62 & 11 \\
\hline 67 & Lung cancer (3) & Cigarette smoker & 23 & 22 & 226 & - & - \\
\hline 65 & Lung cancer (4) & Pipe smoker & 1 & 34 & 47 & 9 & 1 \\
\hline 72 & Lung cancer (5) & Exsmoker (pipe) & 8 & 27 & 1,280 & 3 & 0 \\
\hline 62 & Lung cancer (6) & Exsmoker (pipe) & 1 & 34 & 680 & 15 & 3 \\
\hline 58 & Pancreas cancer & Unknown & 19 & 16 & 300 & 13 & 10 \\
\hline 70 & Pancreas cancer & Unknown & 5 & 38 & 260 & 5 & 6 \\
\hline 73 & Colon cancer & Nonsmoker & 8 & 39 & 570 & - & - \\
\hline 82 & Colon cancer & $\begin{array}{l}\text { Exsmoker (cigarette + } \\
\text { pipe) }\end{array}$ & 17 & 27 & 330 & - & - \\
\hline $\begin{array}{l}84 \\
57\end{array}$ & $\begin{array}{l}\text { Rectal cancer } \\
\text { Cancer of the }\end{array}$ & Exsmoker (cigarette) & 19 & 27 & 430 & - & - \\
\hline & urinary bladder & Pipe smoker & 0 & 24 & 480 & 15 & 2 \\
\hline $\begin{array}{l}61 \\
76\end{array}$ & $\begin{array}{l}\text { Liver cancer } \\
\text { Chronic lymphatic }\end{array}$ & Nonsmoker & 1 & 31 & 260 & 2 & 2 \\
\hline & leukemia & Nonsmoker & 9 & 37 & 106 & 4 & 32 \\
\hline 60 & Myelomatosis & Pipe smoker & 1 & 30 & 330 & - & - \\
\hline 68.6 & $\begin{array}{l}\text { Median values } \\
\text { Mean values }( \pm S D)\end{array}$ & & $8.2 \pm 7.7$ & $30.9 \pm 7.1$ & 330 & 11 & 5 \\
\hline
\end{tabular}

a $1 \mu \mathrm{mol} / \mathrm{kg}=121.8 \mu \mathrm{g} / \mathrm{kg}$.

b Case number in parentheses.

Table 2. Tissue concentrations $(\mu \mathrm{g} / \mathrm{kg}$ wet weight)a of antimony (Sb) in exposed workers with cardiovascular disease.

\begin{tabular}{|c|c|c|c|c|c|c|c|}
\hline $\begin{array}{l}\text { Age } \\
\text { (a) }\end{array}$ & Diagnosis & Smoking habits & $\begin{array}{l}\text { Length of } \\
\text { retirement } \\
\text { (a) }\end{array}$ & $\begin{array}{l}\text { Time of } \\
\text { exposure } \\
\text { (a) }\end{array}$ & $\begin{array}{l}\text { Lung } \\
\mathrm{Sb}\end{array}$ & $\begin{array}{l}\text { Liver } \\
\mathrm{Sb}\end{array}$ & $\begin{array}{c}\text { Kidney } \\
\text { Sb }\end{array}$ \\
\hline 74 & Myocardial infarction & Exsmoker & 7 & 39 & 280 & - & - \\
\hline 65 & Myocardial infarction & Nonsmoker & 6 & 31 & 370 & 12 & 31 \\
\hline 69 & Myocardial infarction & Unknown & 2 & 35 & 23 & 2 & 2 \\
\hline 73 & Myocardial infarction & Cigarette smoker & $\overline{5}$ & 36 & 520 & 二 & 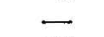 \\
\hline 63 & Myocardial infarction & $\begin{array}{l}\text { Exsmoker } \\
\text { (cigarette + pipe) }\end{array}$ & 5 & 20 & 220 & 17 & 13 \\
\hline 37 & Myocardial infarction & Unknown & 0 & 11 & 33 & 46 & 23 \\
\hline 75 & Myocardial infarction & Nonsmoker & 8 & 34 & 220 & - & - \\
\hline 63 & Myocardial infarction & $\begin{array}{l}\text { Exsmoker } \\
\text { (cigarette + pipe) }\end{array}$ & 4 & 30 & 440 & & \\
\hline 54 & Myocardial infarction & Unknown & 1 & 30 & 540 & 8 & 1 \\
\hline 62 & Myocardial infarction & Cigarette smoker & 0 & 26 & 370 & 22 & 6 \\
\hline 67 & Myocardial infarction & Unknown & 1 & 41 & 790 & - & - \\
\hline 62 & Myocardial infarction & Exsmoker (cigarette) & 4 & 31 & 146 & - & - \\
\hline 66 & Myocardial infarction & Exsmoker (cigarette) & 0 & 40 & 124 & & \\
\hline 69 & Myocardial infarction & Unknown & 4 & 43 & 5,480 & - & - \\
\hline 78 & Cardiosclerosis & Nonsmoker & 15 & 29 & 122 & - & - \\
\hline 64 & Sudden death & Unknown & 1 & 34 & 58 & 54 & 44 \\
\hline \multirow[t]{2}{*}{61} & Sudden death & Unknown & 0 & 42 & 175 & 11 & 2 \\
\hline & Median values & & & & 220 & 15 & 10 \\
\hline 64.8 & Mean values ( \pm SD) & & $3.7 \pm 3.9$ & $32.5 \pm 8.2$ & & & \\
\hline
\end{tabular}

a $1 \mu \mathrm{mol} / \mathrm{kg}=121.8 \mu \mathrm{g} / \mathrm{kg}$. 
the worst work environment of all the departments. In addition he had worked for $29 \mathrm{a}$ in the arsenic and selenium departments where he was also under high exposure. The third highest antimony value was found for a worker who had been a roaster for over 20 a. High antimony concentrations in lung tissue were also found for workers who had worked for a long time in the copper, arsenic, and selenium departments and at the lead smelting furnace.

Among the six cases with lung cancer there were two cigarette smokers, one pipe smoker, and two exsmokers; in one case information was lacking about smoking habits. Among the referents there were eight nonsmokers and one cigarette smoker, and in two cases information was lacking.

The median values for antimony in the lung tissue of the workers did not differ significantly between the smokers $[370 \mu \mathrm{g} / \mathrm{kg}(3.0 \mu \mathrm{mol} / \mathrm{kg})]$, exsmokers [330 $\mu \mathrm{g} / \mathrm{kg}(2.7 \mu \mathrm{mol} / \mathrm{kg})]$, and nonsmokers [280 $\mu \mathrm{g} / \mathrm{kg}(2.3 \mu \mathrm{mol} / \mathrm{kg})]$.

\section{Discussion}

The antimony values of the lung, liver, and kidney tissues of the reference group

Table 3. Tissue concentrations $(\mu \mathrm{g} / \mathrm{kg}$ wet weight)a of antimony (Sb) in exposed workers with other diagnoses.

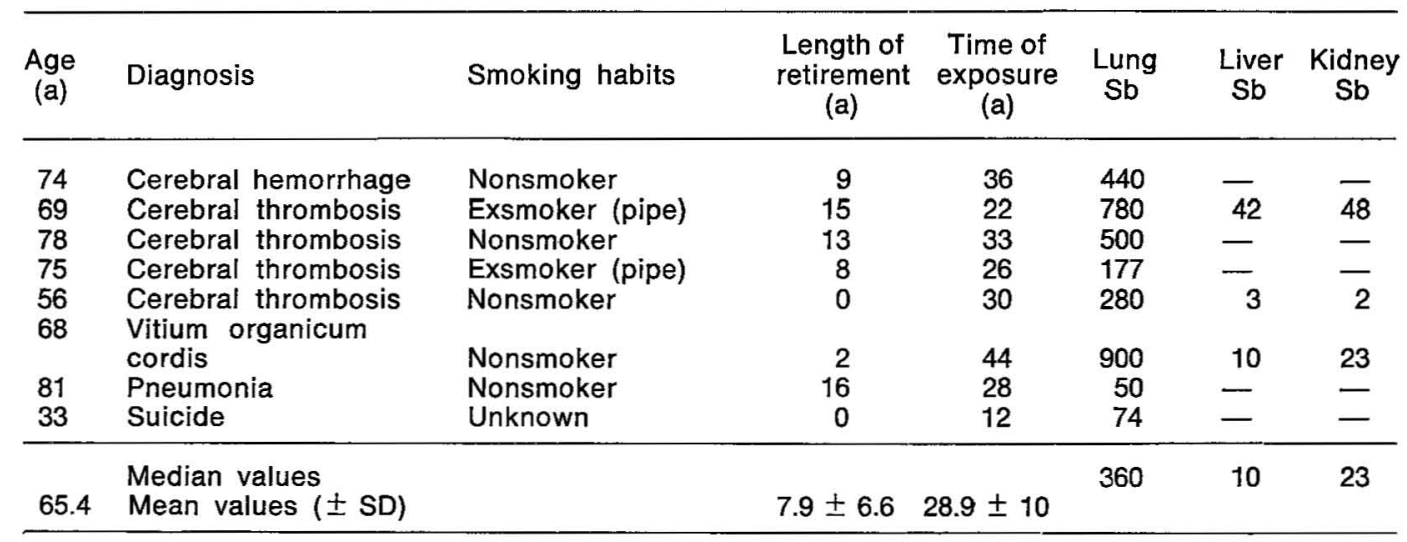

a $1 \mu \mathrm{mol} / \mathrm{kg}=121.8 \mu \mathrm{g} / \mathrm{kg}$.

Table 4. Tissue concentrations ( $\mu \mathrm{g} / \mathrm{kg}$ wet weight)a of antimony (Sb) in the referents.

\begin{tabular}{lllrrr}
\hline $\begin{array}{c}\text { Age } \\
\text { (a) }\end{array}$ & Diagnosis & Smoking habits & $\begin{array}{c}\text { Lung } \\
\text { Sb }\end{array}$ & $\begin{array}{c}\text { Liver } \\
\text { Sb }\end{array}$ & $\begin{array}{c}\text { Kidney } \\
\text { Sb }\end{array}$ \\
\hline 68 & Myocardial infarction & Nonsmoker & 26 & 10 & 4 \\
69 & Myocardial infarction & Nonsmoker & 54 & 13 & 42 \\
68 & Myocardial infarction & Nonsmoker & 32 & 8 & 1 \\
42 & Myocardial infarction & Unknown & 67 & 6 & 30 \\
76 & Myocardial infarction & Unknown & 5 & - & \\
70 & Myocardial infarction & Cigarette smoker & 18 & 5 & 10 \\
75 & Status post, myocardial infarction & Nonsmoker & 37 & 6 \\
76 & Cerebral hemorrhage & Nonsmoker & 16 & 36 & -1 \\
66 & Cerebral hemorrhage & Nonsmoker & 11 & 4 \\
60 & Cerebral hemorrhage & Nonsmoker & 46 & 3 \\
72 & Vitium organicum cordis aortae & Nonsmoker & 26 & 7 & 2 \\
\hline & Median values & & & 5 \\
\hline
\end{tabular}

a $1 \mu \mathrm{mol} / \mathrm{kg}=121.8 \mu \mathrm{g} / \mathrm{kg}$. 
agree well with the normal values that have been reported up to now $(17,19)$. In this study, as in other studies, it was found that lung contains more antimony than liver and kidney tissues $(13,19,31)$. In the present study the antimony concentration of the lung tissue of exposed workers was 12-fold higher than that of the referents $(p<0.001)$. There were many more deaths from malignant disease among the exposed workers than among the referents. There was however no significant difference between the antimony concentration of the lung tissue of workers dead from lung cancer in comparison with that of workers dead from other malignancies, cardiovascular diseases, or other causes.

The antimony values measured for the lung, liver, and kidney tissue of the exposed workers are due to, among other factors, the biological half-time of the element and the conditions of exposure. The time from the last exposure to date of death (length of retirement) varied in our investigation between 0 and 23 a.

For lung tissue there was no tendency towards decreased antimony concentrations with an increasing number of years after the cessation of exposure (fig 1), a finding indicating a long biological halftime $\left(r^{2}=0.002\right)$. No significant differences were found when death occurred $<1,1-5,6-10$ or $11-23$ a after the cessation of exposure.

As stated previously, the median value for the antimony in the liver tissue and kidney cortex of the workers did not dif- fer from the corresponding value of the reference group, a finding indicating either a short biological half-time in these tissues or the insignificance of the systemic distribution of antimony. The exposure time for the workers was 31 a for group I, 33 a for group II, and 29 a for group III.

In this study time of exposure has, due to lack of other data, been equated with the duration of employment. This is not a particularly good measure of the true exposure, as the work conditions at Rönnskärsverken are very complex and they have, in addition, been altered considerably over the last $40 \mathrm{a}$.

Among the workers with the 10 highest antimony values for lung tissue four had been employed $20-40 \mathrm{a}$ in the machine shop. Two of these men started work already in 1930 when the exposure to dust, arsenic, sulfur dioxide, etc, was relatively high. Considerable improvement of the work environment commenced around 1940. In work carried out in the inner workshop, employees also came in contact with asbestos-containing materials and toxic materials that, despite cleaning, could be found in workplaces being repaired. In addition there was exposure to welding fumes, which, for example, could contain high concentrations of chromium, nickel, and other heavy metals. Also, in outdoor work performed throughout the whole factory, the workers were exposed to heavy metals.

Workers dead from cardiovascular diseases (group II) had a significantly shorter

Antimony concentration

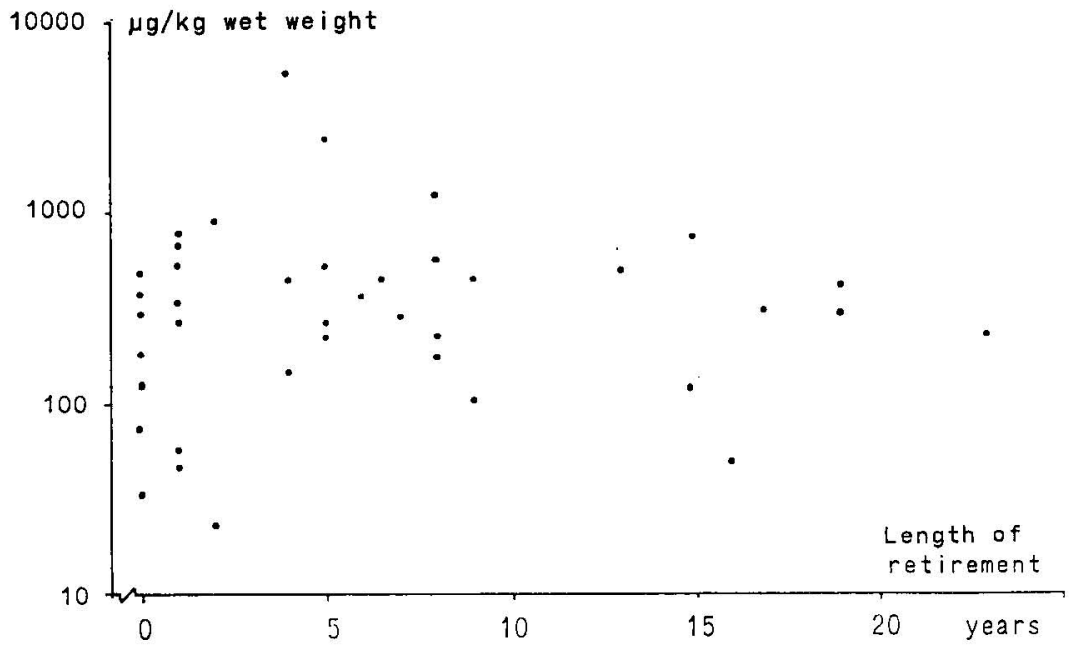

Fig 1. Concentration of antimony in lung tissue
smelter workers in relation to length of retirement. $1 \mu \mathrm{mol} / \mathrm{kg}$ $=121.8 \mu \mathrm{g} / \mathrm{kg}$. 
period of retirement than workers dead from malignancies (group I) or from other causes (group III) $(3.7,8.2$, and 7.9 a, respectively). The shorter period of retirement for group II means that malignancies did not have the same possibility to develop as in the other groups.

Smoking is an established and wellknown risk factor for lung cancer development. In the present study there was a high percentage of smokers and exsmokers among the workers (7 smokers, 11 exsmokers, \& 11 nonsmokers). Information about smoking habits was missing for 11 workers.

Cigarette smoke contains significant amounts of antimony. In one study (25) the antimony concentration was reported to be about $10 \mathrm{mg} / \mathrm{kg}$ in tobacco, 35-60 $\mathrm{mg} / \mathrm{kg}$ in smoke condensate, and about $12-20 \mathrm{mg} / \mathrm{kg}$ in cigarette ashes. A higher transference of antimony to smoke condensate appeared in nonfilter cigarettes than in filter cigarettes. Thus cigarette smoking can be a factor contributing to the higher concentrations of antimony in the lung tissue of the exposed workers.

As already pointed out in an earlier report on this material (35), the highest concentrations of antimony, arsenic, cadmium, lanthanum, and lead were found among the six cases with lung cancer.

According to Wester (35) and also Nordberg \& Andersen (26), it is at present impossible to show any single cause for the development of lung cancer in smelter workers. In addition to smoking, a documented risk factor, both toxic gases and potential carcinogenic substances with a long biological half-time in the lung, eg, antimony, must be considered. Interaction between some of the substances mentioned has been found in animal experiments [reviewed by Nordberg \& Andersen (26)] and can be considered as likely to have occurred also in the present exposure situation. A multifactorial genesis is at present the most likely. The possibility of a significant contribution of antimony to the risk for the development of lung cancer is supported by recent carcinogenicity studies with animals (33 \& Reeves AL, personal communication 1981).

The multielement analysis of tissues from exposed workers in conjunction with systematic occupational hygiene surveys would give better information on the underlying causes. The long latency time for the development of lung cancer is however a complicating factor.

Currently exposure profiles are under development for future use in epidemiologic long-term studies. These profiles will allow more specific quantifications of the exposure patterns and their changes with time $(3,7,11)$. In such studies trace element analysis would be of increased importance.

\section{Acknowledgment}

Financial support was given by the Swedish Work Environment Fund project no $80 / 107$.

\section{References}

1. Brune D, Nordberg GF, Wester PO. Distribution of 23 elements in the kidney, liver and lungs of workers from a smeltery and refinery in north Sweden exposed to a number of elements and of a control group. Sci total environ 16 (1980) 13-35.

2. Brune D, Nordberg GF, Wester PO, Bivered $B$. Accumulation of heavy metals in tissues of industrially exposed workers. In: International Atomic Energy Agency. Nuclear activation techniques in the life sciences. Vienna 1979 (IAEA-SM-227/12).

3. Conibear SA, Carnow BW. Assessment of exposure and risk through use of a personal, cumulative organ risk index. Presented at the XIX International Congress of Occupational Health, Dubrovnik, September 1978.

4. Cooper DA, Pendergrass EP, Vorwald AJ, Mayock RL, Brieger $H$. Pneumoconiosis among workers in an antimony industry. Am $\mathrm{j}$ roentgenol radium ther nucl med 103 (1968) 495-508.

5. Cordasco EM. Newer concepts in the management of environmental pulmonary edema. Angiology 25 (1974) 590-601.

6. Cordasco EM, Stone FD. Pulmonary edema of environmental origin. Chest 64 (1973): 2, $182-185$.

7. Corn M, Esmen NA. Workplace exposure zones for classification of employee exposures to physical and chemical agents. Am ind hyg $\mathrm{j} 40$ (1979) 47-57.

8. Elinder C-G, Friberg L. Antimony. In: Friberg L, Nordberg GF, Vouk VB, ed. Handbook on the toxicology of metals. Elsevier/North-Holland Biomedical Press, Amsterdam 1979, pp 283-292.

9. Feil A. Le rôle de l'antimoine en pathologie professionnelle. Presse med 57 (1939) 1133-1134.

10. Felicetti SW, Thomas RG, McClellan RO. 
Retention of inhaled antimony-124 in the beagle $\operatorname{dog}$ as a function of temperature of aerosol formation. Health phys 26 (1974) $525-531$.

11. Gamble J, Spirtas R. Job classification and utilization of complete work histories in occupational epidemiology. $\mathrm{J}$ occup med 18 (1976) 399-404.

12. Gross P, Westrick ML, Brown JHU, Srsic RP, Schrenk HH, Hatch TF. Toxicologic study of calcium halophosphate phosphors and antimony trioxide: II Pulmonary studies. Arch ind health 1 (1955) 479-486.

13. Hamilton EI, Minski MJ, Cleary JJ. The concentration and distribution of some stable elements in healthy human tissues from the United Kingdom. Sci total environ $1(1972 / 1973) 341-374$.

14. Harding-Barlow I. Studies on the trace element content of human tissues. Doctoral dissertation. The University of Capetown, Capetown 1961.

15. Karajovic D, Potkonjak V, Gospavic J. Die Silikoantimonose. Arch Gewerbepathol Gewerbehyg 17 (1960) 651-665.

16. Le Gall. Pneumoconioses et antimoine. Arch mal prof med trav séc 30 (1968) 361362.

17. Lievens $P$, Versieck $J$, Cornelis R, Hoste $J$. The distribution of trace elements in normal human liver determined by semiautomated radiochemical neutron activation analysis. $J$ radioanal chem 37 (1977) $483-496$.

18. Lundberg I. Antimony: A review of the literature on medical and toxicological observations. Swedish National Board of Health and Safety, Solna 1978. (Arbete och hälsa no 1978-1).

19. Lyengar GV, Kollmer WE, Bowen HJM. The elemental composition of human tissues and body fluids. Verlag Chemie Weinheim, New York NY 1978.

20. McCallum RI. The work of an occupational hygiene service in environmental control. Ann occup hyg 6 (1963) 55-64.

21. McCallum RI. The health of antimony process workers. In: Proceedings of the 15th international congress on occupational health. Vienna II: 1.1966 , pp 293-296.

22. McCallum RI. Detection of antimony in process workers' lungs by $\mathrm{x}$-radiation. Trans soc occup med 17 (1967) 134-138.

23. McCallum RI, Day MJ. In-vivo method for detecting antimony deposits in the lung by differentiated absorption of x-radiation. Lancet 2 (1965) 882-883.

24. McCallum RI, Day MJ, Underhill J, Aird EGA. Measurement of antimony oxide dust in human lungs in vivo by $x$-ray spectrophotometry. In: British Occupational Hygiene Society. Inhaled particles proceedings III: 2. Cambridge 1971, pp 611618.

25. Nadkarni RA, Ehmann WD. Transference studies of trace elements from cigarette tobacco into smoke condensate, and their determination by neutron activation analysis. In: University of Kentucky. Proceedings tobacco health conference, Report 2. Lexington, KY 1970, pp 37-45.

26. Nordberg GF, Andersen O. Metal interactions in carcinogenesis: Enhancement, inhibition. Environ health perspect 40 (1981) $65-81$.

27. Nordberg GF, Wester PO, Brune D. Tissue levels of 25 elements in smelter workers. In: International Labor Organization. Proceedings of international symposium control of air pollution in the working environment: Part III. Geneva 1978, pp 261272.

28. Perry HM Jr, Tipton IH, Schroeder HA, Cook MJ. Variability in the metal content of human organs. J lab clin med 60 (1962) $245-253$.

29. Renes LE. Antimony poisoning in industry. Arch ind hyg occup med 7 (1953) 99108.

30. Samsahl K, Wester PO, Landström O. An automatic group separation system for the simultaneous determination of a great number of elements in biological material. Anal chem 40 (1968) 181-187.

31. Schicha $H$, Kasperek $K$, Feinendegen LE, Siller V, Klein HJ. Aktivierungsanalytische Messungen einer inhomogenen teilweise parallel verlaufenden Verteilung von Kobalt, Eisen, Selen, Zink und Antimon in verschiedenen Bezirken von Leber, Lunge, Niere, Herz und Aorta. Beitr Pathol 146 (1972) 55-62.

32. Wall S. Survival and mortality pattern among Swedish smelter workers. Int $\mathrm{j}$ epidemiol 9 (1980) $73-87$.

33. Watt WD, Kerfoot EJ. Neoplastic effects of antimony trioxide. Paper presented at the 21st annual american industrial hygiene conference, Portland, OR May 28, 1981.

34. Wester PO. Trace elements in heart tissue. Acta med scand suppl 439 (1965) 1-48.

35. Wester PO, Brune D, Nordberg GF. Arsenic and selenium in lung, liver and kidney tissue from dead smelter workers. $\mathrm{Br} \mathrm{j}$ ind med 38 (1981) 179-184.

Received for publication: 1 February 1982 